\title{
Trophic effect of gastrin on the enterochromaffin like cells of the rat stomach: Establishment of a dose response relationship
}

\author{
E Brenna, H L Waldum
}

\begin{abstract}
Gastrin was given to rats by continuous subcutaneous infusion through implanted osmotic minipumps in doses covering a wide range of the dose response relationship for gastrin with regard to the trophic effect on the enterochromaffin like cells of the oxyntic mucosa. Thirty five rats were divided into five groups (each of seven rats), one group receiving a control solution of $1 \%$ albumin, the others receiving gastrin in $1 \%$ albumin at doses of 2.5 , 5,10 , and $15 \mu \mathrm{g} / \mathrm{kg} / \mathrm{h}$, respectively. The plasma gastrin concentrations in the various groups increased in the same order of magnitude as expected from the gastrin doses given. Gastrin induced a dose dependent increase in enterochromaffin like cell density, oxyntic mucosal histamine concentration and histidine decarboxylase activity up to the dose of $5 \mu \mathrm{g} /$ $\mathrm{kg} / \mathrm{h}$, where the increase levelled off. Hence, the dose response relationship for the trophic effect of gastrin on the enterochromaffin like cells seems to follow a polynomial rather than a linear function. These findings may also contribute to the understanding of the trophic effect of gastrin on enterochromaffin like cells in man with conditions associated with hypergastrinaemia.
\end{abstract}

(Gut 1992; 33: 1303-1306)

It is generally accepted that gastrin controls the growth of the enterochromaffin like cells of the oxyntic mucosa. ${ }^{1}$ Thus, profound inhibition of acid secretion by omeprazole ${ }^{23}$ or histamine 2 receptor blockers in the rat $^{3}$ led to endogenous hypergastrinaemia and enterochromaffin like cell hyperplasia. The hypergastrinaemia and enterochromaffin like cell hyperplasia induced by these agents were abolished by antrectomy. ${ }^{2}$ Furthermore, hypergastrinaemia after antrum exclusion $^{4}$ or partial gastric corpectomy ${ }^{5}$ and exogenous hypergastrinaemia induced by continuous infusion of gastrin evoked proliferation of the enterochromaffin like cells in the rat stomach. ${ }^{6}$ Therefore acid inhibition is not a prerequisite for the hyperplasia. It has been suggested that there is a linear correlation between plasma gastrin concentration and the enterochromaffin like cell density ${ }^{2}$ in the oxyntic mucosa of the rat. No report has fully established the relationship between the gastrin concentration and the trophic effect on the enterochro- maffin like cell, however, as neither the minimal nor the maximal effective gastrin concentration with regard to the trophic effect on the enterochromaffin like cell has been assessed. From the study of Larsson $e t a l,{ }^{2}$ it could appear that the number of enterochromaffin like cells would increase infinitely with the gastrin concentration. In the rat, the enterochromaffin like cells produce and store most of the histamine in the oxyntic mucosa. ${ }^{7-9}$ From our laboratory, it has previously been reported that the acid stimulatory effect of gastrin can be fully explained by the stimulation of histamine release. ${ }^{10}$ Gastrin induced histamine release in a concentrationdependent fashion with threshold concentration of $2 \mathrm{pmol} / \mathrm{l}$ and reaching a maximum effect at a gastrin concentration of about $260-520 \mathrm{pmol} /$ 1. ${ }^{112}$ Furthermore, the histamine synthesising enzyme, histidine decarboxylase, ${ }^{13}$ and the histidine decarboxylase mRNA abundance ${ }^{14}$ are regulated by gastrin. The present study was done to establish a dose response relationship for the trophic effect of gastrin on the enterochromaffin like cells by giving exogenous gastrin in graded doses.

\section{Methods}

ANIMALS

The procedure described by Ryberg et $a l^{6}$ was followed. Thirty five female Sprague-Dawley rats each weighing approximately $200 \mathrm{~g}$, were used. The animals were divided into five different groups, each group consisting of seven rats. One group was given a control solution ( $1 \%$ albumin) and the other four groups were given [Leu ${ }^{15}$ ]-gastrin-17 (L-G-17) in $1 \%$ albumin in the doses shown in the Table. Human L-G-17 and albumin were purchased from Sigma (St Louis, Mo, USA). L-G-17 or the control solution was administered subcutaneously through osmotic minipumps (ALZET $2 \mathrm{ML1}$, ALZA Corp, Palo Alto, Calif, USA) implanted on the back of the rats under general anaesthesia $(0.2 \mathrm{ml}$ $100 \mathrm{~g} /$ body weight of a solution containing fluanisone $2.5 \mathrm{mg} / \mathrm{ml}$, phentanyl $0.05 \mathrm{mg} / \mathrm{ml}$, and midazolam $1.25 \mathrm{mg} / \mathrm{ml}$ ). The animals were treated for 28 days and the minipumps were changed every seventh day.

At day 28, the rats were bled by heart puncture under general anaesthesia (as described above). The stomach was removed, opened along the 
Effects of different doses of exogenous [Leu ${ }^{15}$-gastrin-17 on the oxyntic mucosa of the rat stomach

\begin{tabular}{|c|c|c|c|c|c|}
\hline & \multicolumn{5}{|l|}{ Gastrin dose } \\
\hline & Control & $2.5 \mu \mathrm{g} / \mathrm{kg} / \mathrm{h}$ & $5 \mu g / k g / h$ & $10 \mu g / k g / h$ & $15 \mu g / k g / h$ \\
\hline $\begin{array}{l}\text { Rats (n) } \\
\text { P-gastrin (pmol/l) } \\
\text { Stomach weight (g) } \\
\text { Weight of oxyntic mucosa (g) }\end{array}$ & $\begin{array}{l}7 \\
37 \cdot 4(4 \cdot 7) \\
1 \cdot 455(0 \cdot 029) \\
0 \cdot 254(0 \cdot 013)\end{array}$ & $\begin{array}{l}6 \\
103 \cdot 2(16 \cdot 6) \\
1 \cdot 562(0 \cdot 040) \\
0 \cdot 332(0 \cdot 025)\end{array}$ & $\begin{array}{l}\stackrel{7}{214 \cdot 0(27 \cdot 1)} \\
1 \cdot 619(0 \cdot 030) \\
0 \cdot 313(0 \cdot 018)\end{array}$ & $\begin{array}{l}\quad 7 \\
441 \cdot 1(74 \cdot 9) \\
1 \cdot 593(0 \cdot 043) \\
0 \cdot 326(0 \cdot 017)\end{array}$ & $\begin{array}{l}7 \\
536 \cdot 4(112 \cdot 2) \\
1.656(0.053) \\
0.356(0.031)\end{array}$ \\
\hline
\end{tabular}

All results are expressed as mean (SE).

greater curvature, rinsed in ice cold $0.9 \%$ saline and weighed. Subsequently the stomach was laid out on a glass plate and a tissue specimen, $4 \mathrm{~mm}$ in diameter, was taken by a punch press from the anterior wall on the greater curvature. The antrum was discarded and the oxyntic mucosa scraped off, weighed, diluted to $100 \mathrm{mg} / \mathrm{ml}$ in ice cold $0.01 \mathrm{M}$ sodium phosphate buffer, $\mathrm{pH} 7 \cdot 4$, and homogenised. Aliquots of the homogenates were stored at $-70^{\circ} \mathrm{C}$ for later determination of the histidine decarboxylase activity. One portion of the homogenates was boiled for 10 minutes, centrifuged at $5000 \mathrm{~g}$ for 10 minutes and the supernatant stored at $-20^{\circ} \mathrm{C}$ for the later determination of histamine. The tissue specimens were fixed overnight in freshly prepared Stefanini's solution ${ }^{15}$ with $1 \%$ (weight/volume) 1 ethyl-3(3-dimethylaminopropyl)-carbodiimide (Sigma) ${ }^{16}$ dehydrated in ethanol, and embedded in paraffin.

The study was approved by the animal welfare committee at the University Hospital of Trondheim.

\section{PLASMA GASTRIN}

Plasma gastrin concentration was determined in $200 \mu \mathrm{l}$ plasma using a double antibody liquid phase ${ }^{125}$ I-radioimmunoassay (Diagnostic Products Corporation, Los Angeles, Calif, USA). These antibodies have the same immunoreactivity towards L-G-17 and gastrin-17 (unpublished data). Results are expressed as pmol equivalents of synthetic human gastrin 17/1 plasma.

HISTAMINE IN OXYNTIC MUCOSA

The determination of histamine in the oxyntic mucosal homogenates was performed using a commercially available radioimmunoassay kit (Immunotech, Marseilles, France) with high specificity and sensitivity. ${ }^{17}$ Results are expressed as nmol histamine/g wet weight of oxyntic mucosa.

HISTIDINE DECARBOXYLASE ACTIVITY

The microprocedure described by Beaven $e t a l^{18}$ with some modifications ${ }^{2}$ was used. We incubated $80 \mu$ l oxyntic mucosal homogenate with [1-14 C]L-histidine ( $24 \mathrm{nCi}, 0.48 \mathrm{nmol}$; New England Nuclear, Boston, Mass, USA), $5 \cdot 10^{-4}$ $M$ L-histidine, and $10^{-5} \mathrm{M}$ pyridoxal-5phosphate in a total reaction volume of $160 \mu \mathrm{l}$ at $37^{\circ} \mathrm{C}$ for 60 minutes. The reaction was stopped by adding $80 \mu \mathrm{l} 2 \mathrm{M}$ perchloric acid followed by an incubation at $37^{\circ} \mathrm{C}$ for 30 minutes. The expelled ${ }^{14} \mathrm{CO}_{2}$ was trapped in $50 \mu \mathrm{l}$ Protosol
(New England Nuclear) and counted after adding scintillation fluid. Results are expressed as pmol ${ }^{14} \mathrm{CO}_{2} / \mathrm{mg}$ wet weight per hour.

\section{MORPHOMETRIC ANALYSES}

Sections of $5 \mu \mathrm{m}$ thickness were cut perpendicular to the mucosal surface. For the determination of enterochromaffin like cells, specimens were stained with histamine antibodies ${ }^{19}$ no. 8531 (Milab, Malmö, Sweden, kindly provided by Prof R Håkanson, University of Lund, Sweden) and visualised using the peroxydase antiperoxydase reaction. In the rat this method can be regarded as specific for the enterochromaffin like cells, because the mast cells are few in the mucosa and restricted to the superficial layer. ${ }^{19}$ The enterochromaffin like cell density was determined in randomly selected fields. An eye piece $\times 10$ with an ocular grid inserted and an objective $\times 40$ were used. Epithelial cells located between the lines of the grid $(0.25 \mathrm{~mm}$ mucosal length $)$ in at least three visual fields in two different sections from each specimen were counted. Only enterochromaffin like cells with a visible nucleus were counted. The enterochromaffin like cell density is expressed as number of cells per mm mucosal length. The specimens were coded and the examiner was unaware of the group to which they belonged.

\section{STATISTICAL ANALYSIS}

A non-parametric one way analysis of variance, the Kruskal-Wallis H-test, was used for examination of a global difference between all groups. When significance was indicated, the two sample Mann-Whitney U-test was applied. All values are given as mean (SE). The level of statistical significance was set at 0.05 .

\section{Results}

The results are summarised in the Table and Figure. The plasma gastrin concentrations increased from group to group as expected from the dose given. The rat weights did not differ between the groups. There was a significant increase in the weight of the whole stomach and oxyntic mucosa $(p=0.030$ and $p=0.018$, respectively). These differences were mostly caused by the increase in the weights in the treated groups compared with the control group.

The enterochromaffin like cell density increased from $66(7)$ in the control group to 78 (12) (NS) in the group receiving $2.5 \mu \mathrm{g} / \mathrm{kg} / \mathrm{h}$ and to $127(12)(p=0.002)$ in the group receiving 5.0 $\mu \mathrm{g} / \mathrm{kg} / \mathrm{h}$. The mucosal histamine content increased from $264 \cdot 1(20 \cdot 1) \mathrm{nmol} / \mathrm{g}$ to $379 \cdot 0$ 

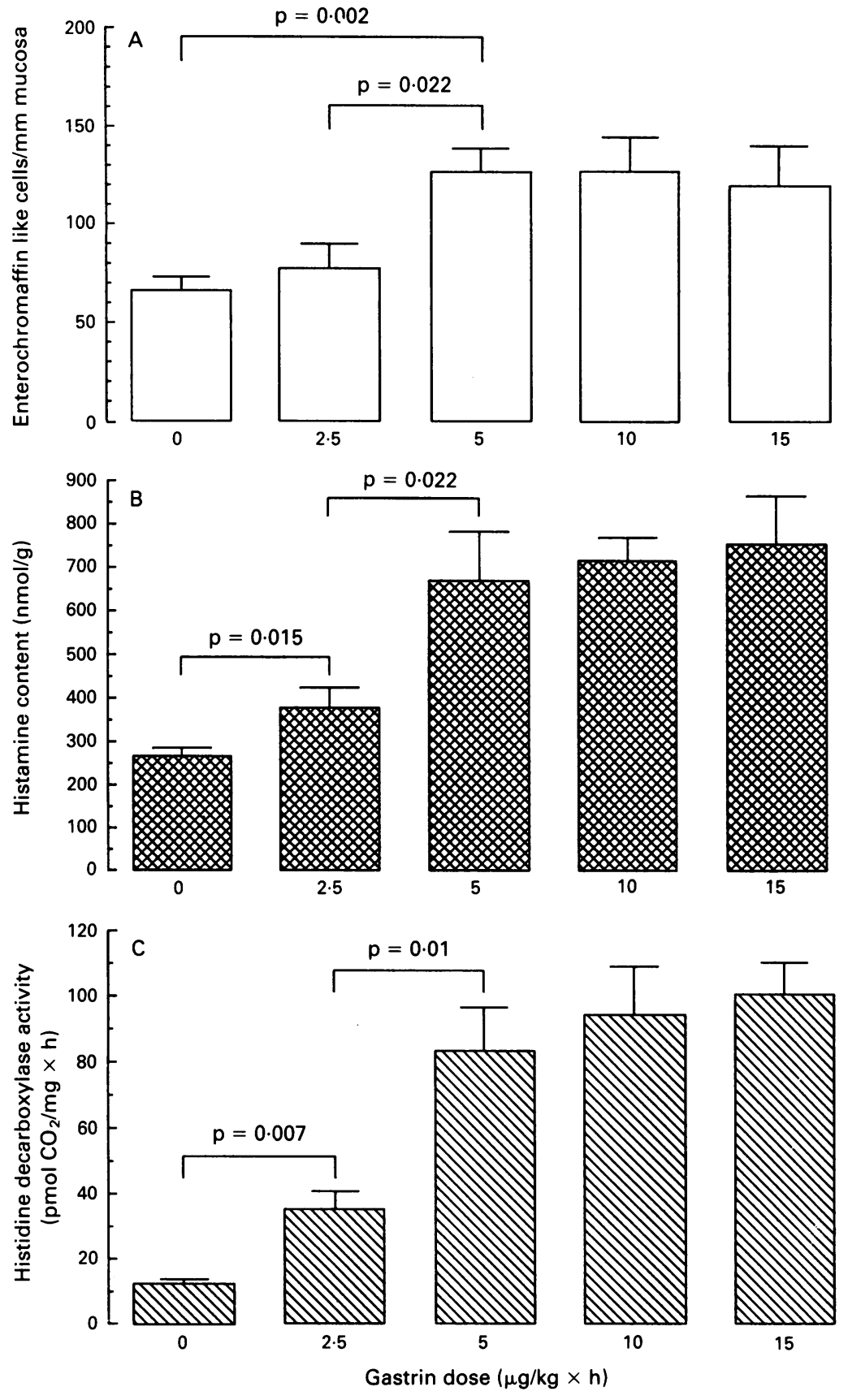

Density of enterochromaffin like $(E C L)$ cells $(A)$, histamine content $(B)$, and histidine decarboxylase activity $(C)$ in the oxyntic mucosa of the rat after continuous, subcutaneous treatment with various doses of [Leu ${ }^{-15}$-gastrin-17 for 28 days. All values are mean (ISE).

$(45 \cdot 5) \mathrm{nmol} / \mathrm{g}(\mathrm{p}=0.015)$ in the group receiving $2.5 \mu \mathrm{g} / \mathrm{kg} / \mathrm{h}$. There was a further significant increase to $670.9(112.2)(p=0.022)$ in the group receiving $5.0 \mu \mathrm{g} / \mathrm{kg} / \mathrm{h}$. The histidine decarboxylase activity increased from $12 \cdot 8(1 \cdot 8) \mathrm{pmol}$ $\mathrm{CO}_{2} / \mathrm{mg} / \mathrm{h}$ to $35 \cdot 5(5 \cdot 5) \mathrm{pmol} \mathrm{CO}_{2} / \mathrm{mg} / \mathrm{h}(\mathrm{p}=$ 0.007 ) in the group receiving $2.5 \mu \mathrm{g} / \mathrm{kg} / \mathrm{h}$. There was also a further increase in histidine decarboxylase activity to $83 \cdot 7(12 \cdot 9) \mathrm{pmol} \mathrm{CO}_{2} / \mathrm{mg} / \mathrm{h}(\mathrm{p}=$ $0 \cdot 01$ ) with increasing gastrin dose from $2 \cdot 5 \mu \mathrm{g} /$ $\mathrm{kg} / \mathrm{h}$ to $5 \cdot 0 \mu \mathrm{g} / \mathrm{kg} / \mathrm{h}$. There was no significant difference in enterochromaffin like cell density, histamine content or histidine decarboxylase activity between the groups receiving the three highest gastrin doses. Thus, for all three enterochromaffin like cell parameters, the dose response curves fitted a quadratic function compatible with a maximal effect of gastrin within the given dose range.

\section{Discussion}

For the first time a wide range dose response relationship for the trophic effect of gastrin on the enterochromaffin like cells of the rat stomach has been established. The dose response curve for the trophic effect of gastrin is best described by a quadratic function with a maximal effect of gastrin at a plasma concentration in the range 250-400 pmol/1. Thus, the enterochromaffin like cell density, histamine content and histidine decarboxylase activity of the oxyntic mucosa all increased with increasing gastrin dose up to a maximal level at a gastrin concentration in the same range as found for the maximal histamine releasing and acid stimulatory effect of gastrin. " 12 Hence, the histamine releasing and trophic effect of gastrin on the enterochromaffin like cells show about the same concentration dependence with regard to the minimal concentration of gastrin causing maximal effect. This may suggest that the histamine releasing and the trophic effects of gastrin on the enterochromaffin like cells are mediated by interaction with the same receptor.

Ryberg et $a l^{6}$ using the same radioimmunoassay for determination of plasma gastrin, found higher concentrations for the corresponding gastrin doses than we did. The basal gastrin concentration, however, was also proportionately lower in the present study. Furthermore, Ryberg et $a l^{6}$ showed that continuous infusion of L-G-17 through osmotic minipumps gave somewhat lower plasma gastrin concentrations just before the pumps were changed. Therefore, the gastrin concentrations in the present study are probably measured at the lowest level. The linear relationship between plasma gastrin concentration and the enterochromaffin like cell density previously reported ${ }^{20}$ may only reflect a more prolonged endogenous hypergastrinaemia in those with the highest gastrin concentration two hours after administration of the drug. In the study by Ryberg et $\mathrm{l}^{6}$ gastrin was probably given in such a dose that the gastrin concentration just reached the maximal effective level. In another study by Ryberg $e a^{21}$ the enterochromaffin like cell labelling index was shown to increase linearly with the plasma gastrin concentration. From their figure, however, it can be extrapolated that the labelling index tended to level off, at a gastrin concentration corresponding to the lowest concentration giving maximal effect in the present study. In the study by Mattsson $e t a l^{22}$ describing development of enterochromaffin like carcinoids in rats after long term hypergastrinaemia caused by partial corpectomy, the plasma gastrin concentration might have been above the minimal concentration necessary to give maximal trophic effect (supramaximal concentration).

Extrapolation of data from rat to man is difficult, but it is tempting to speculate that the findings in the present study may have its parallel in man and explain some findings reported in patients with diseases accompanied by hypergastrinemia. Blair et $a l^{23}$ reported that circulating gastrin accounted for approximately $90 \%$ of acid secretion in response to eating. They found that on average, a gastrin concentration of $1000 \mathrm{pg} / \mathrm{ml}$ $(\approx 500 \mathrm{pmol} / \mathrm{l})$ gave maximal gastric acid 
stimulation. ${ }^{23}$ In man and other species, there is accumulating evidence that gastrin stimulates acid secretion by releasing histamine. ${ }^{102425}$ Furthermore, there is no relationship between the magnitude of the hypergastrinaemia and the density of argyrophilic cells in patients with the Zollinger-Ellison syndrome, ${ }^{26}$ which may indicate that there also in man exists a maximal gastrin concentration above which no further trophic effect on enterochromaffin like cells may be obtained. Hence, many of these patients may actually have supramaximal gastrin concentrations. Similar findings were also reported by Sjöblom et $a l^{27}{ }^{28}$ studying patients with pernicious anaemia. They found that patients with the highest serum gastrin concentrations did not necessarily have the highest enterochromaffin like cell counts. In fact, from their data it can be extrapolated that the maximal trophic effect of gastrin occurs at a concentration of approximately $500 \mathrm{pmol} / 1 .{ }^{27} 28$ Moreover, they also showed that patients with pernicious anaemia and carcinoid tumours or nodular argyrophilic cell hyperplasia did not have the highest serum gastrin concentrations. ${ }^{27} 28$ These patients were characterised by an early onset and long duration of pernicious anaemia. ${ }^{27} 28$ These data may therefore indicate that when the gastrin concentration giving maximal trophic effect is reached, further growth of the enterochromaffin like cells is dependent on the duration of the hypergastrinaemia. Furthermore, Cattan et $a l^{29}$ reported that in patients with atrophic gastritis, the gastrinaemia was similar for patients with slight, moderate, and marked hyperplasia of argyrophilic cells.

Our findings may also have clinical implications concerning long term treatment of acid related disorders with potent inhibitors of acid secretion. According to our findings, hypergastrinaemia above a certain level will have the same trophic effect on the enterochromaffin like cells. In man the lowest maximal effective gastrin concentration may, however, vary between individuals, analogous to the interindividual differences described for the gastrin concentration giving maximal gastric acid stimulation..$^{23}$

In conclusion, the present study indicates that there is an increasing enterochromaffin like cell density with increasing gastrin concentration up to a certain level, and increasing the gastrin concentration above this level does not lead to further hyperplasia.

The authors would like to thank Britt S Søgnen, Anne Kristensen, Anne Grete Restad and Sissel Holm-Olsen for their technical assistance. This study was supported by the Norwegian Council for Science and the Humanities and by the Cancer Fund at the University Hospital, Trondheim.

1 Håkanson R, Sundler F. Proposed mechanism of induction of gastric carcinoids: the gastrin hypothesis. Eur $\mathcal{F}$ Clin Invest gastric carcinoids: the gas
1990; 20 (suppl 1): $65-71$.

2 Larsson H Carlsson E, Mattsson H, Lundell L, Sundler F, Sundell G, et al. Plasma gastrin and gastric enterochromaffinlike cell activ

3 Ryberg B, Bishop AE, Bloom SR, Carlsson E, Håkanson R, Larsson $\mathrm{H}$, et al. Omeprazole and ranitidine, antisecretagogues with different modes of action, are equally effective in causing hyperplasia of enterochromaffin-like cells in rat stomach. Regul Pept 1989; 25: 235-46.

4 Håkanson R, Ekelund M, Sundler F. Activation and proliferation of gastric endocrine cells. In: Falkmer S, Håkanson R, Sundler F, eds. Evolution and tumour pathology of the neuroendocrine system. Fernström Foundation Series. Vol 4 Amsterdam: Elsevier, 1984: 371-98.

5 Ryberg B, Carlsson E, Carlsson K, Håkanson R, Lundell L, Mattson $\mathrm{H}$, et al. Effects of partial resection of acid secretin mucosa on plasma gastrin and enterolchromaffin-like cells in the rat stomach. Digestion 1990; 45: 102-8.

6 Ryberg B, Axelson J, Håkanson R, Sundler, Mattson H. Trophic effects of continuous infusion of $\left(\mathrm{Leu}^{15}\right)$-gastrin-17 in the rat. Gastroenterology 1990; 98: 33-8.

7 Thunberg R. Localization of cells containing and forming histamine in the gastric mucosa of the rat. Exp Cell Res 1967; 47: $108-15$.

8 Rubin W, Schwartz B. Electron microscopic radioautographic identification of the ECL cell as the histamine-synthesizing endocrine cell in the rat stomach. Gastroenterology 1979; 77 : 458-67.

9 Panula P, Kaartinen M, Mäcklin M, Costa E. Histaminecontaining peripheral nueronal and endoctine systems. F Histochem Cytochem 1985; 33: 933-41.

10 Waldum HL, Sandvik AK, Brenna E, Petersen H. Gastrinhistamine sequence in the regulation of gastric acid secretion. Gut 1991; 32: 698-701.

11 Sandvik AK, Waldum HL, Kleveland PM, Schulze Søgnen B. Gastrin produces an immediate and dose-dependent histamine release preceding acid secretion in the totally isolated, vascularly perfused rat stomach. Scand $f$ Golated, vascularly 2 perfused

12 Sandvik AK, Waldum HL. Rat gastric histamine release: A sensitive gastrin bioassay. Life Sci 1990; 46: 453-9.

13 Håkanson R, Kroesen JH, Liedberg G, Oscarson J, Rehfeld JF, Stadil F. Correlation between serum gastrin concentration and rat stomach histidine decarboxylase activity. F Physiol 1974; 243: 483-98.

14 Dimaline R, Sandvik AK. Histidine decarboxylase gene expression in rat fundus is regulated by gastrin. FEBS Lett 1991; 281: 20-2.

15 Stefanini M, De Martino C, Zamboni L. Fixation of ejaculated spermatozoa for electron microscopy. Nature 1967; 216: 173-4

16 Panula $\mathrm{P}$, Häppölä $\mathrm{O}$, Airaksinen MS, Auvinen S, Virkamäki A. Carbodiimide as a tissue fixative in histamine immunohistochemistry and its application in developmenta neurobiology. F Histochem Cytochem 1988; 36: 259-69.

7 Waldum HL, Brenna E, Sandvik AK, Kleveland PM, Petersen H, Søgnen B. Histamine and gastrin in plasma of patients with upper gastrointestinal diseases. Digestion 1989; 42: 121-7.

18 Beaven MA, Wilcox G, Terpstra GK. A microprocedure for the measurement of ${ }^{14} \mathrm{CO}_{2}$ release from $\left[{ }^{14} \mathrm{C}\right]$ carboxyllabeled amino acids. Anal Biochem 1978; 84: 638-41.

19 Håkanson R, Böttcher G, Ekblad E, Panula P, Simonsson M, Dohlsten $M$, et al. Histamine in endocrine cells in the stomach. Histochemistry 1986; 86: 5-17.

20 Larsson $H$, Carlsson E, Håkanson $R$, Mattsson $H$, Nilsson $G$, Seensalu $R$, et al. Time-course of development and reversal of gastric endocrine cell hyperplasia after inhibition of acid of gastric endocrine cell hyperplasia after inh

21 Ryberg B, Tielemans Y, Axelson J, Carlsson E, Håkanson R, Mattsson $\mathrm{H}$, et al. Gastrin stimulates the self-replication rate of enterochromaffinlike cells in the rat stomach. Gastroenterology 1990; 99: 935-42.

22 Mattsson H, Havu N. Bräutigam J, Carlsson K, Lundell L, Carlsson E. Partial gastric corpectomy results in hypergastrinemia and development of gastric enterochromaffinlike-cell carcinoids in the rat. Gastroenterology 1991; 100: $311-9$.

23 Blair AJ, Richardson CT, Walsh JH, Feldman M. Variable contribution.of gastrin to gastric acid secretion after a meal in contribution.of gastrin to gastric acid secretion

24 Leth R, Olbe L, Haglund U. The pentagastrin-induced gastric acid response in humans. Scand 7 Gastroenterol 1988; 23: 224-8.

25 Lönroth H, Rosengren E, Olbe L, Lundell L. Histamine metabolism in human gastric mucosa. Effect of pentagastrin stimulation. Gastroenterology 1990; 98: 921-8.

26 Maton PN, Lack EE, Collen MJ, Cornelius MJ, David E, Gardner JD, et al. The effect of Zollinger-Ellison syndrome and omeprazole therapy on gastric oxyntic endocrine cells. Gastroenterology 1990; 99: 943-50.

27 Sjöblom S-M, Sipponen $P$, Karonen S-L, Järvinen $H J$. Mucosal argyrophil endocrine cells in pernicious anaemia and upper gastrointestinal carcinoid tumours. $\mathcal{F}$ Clin Pathol and upper gastroin

28 Sjöblom S-M, Sipponen $P$, Karonen S-L, Järvinen $H J$. Argyrophil cell hyperplasia and carcinoid tumours in Argyrophil cell hyperplasia and carcinoid tumours in oxyntic mucosa of the stomach. Dependence on duration of pernicious

29 Cattan D, Roycayrol A-M, Launay J-M, Callebert J, Charasz $\mathrm{N}$, Nurit $\mathrm{Y}$, et al. Circulating gastrin, endocrine cells, histamine content, and histidine decarboxylase activity in atrophic gastritis. Gastroenterology 1989; 97: 586-96. 